\title{
Ogórki małosolne antropomorfizowane. Próby o wierszu Za szkłem
}

\begin{abstract}
Poprawa Adam, Ogórki małosolne antropomorfizowane. Próby o wierszu "Za szkłem" [Anthropomorphised freshly pickled gherkins. Attempts at the poem Behind glass]. „Przestrzenie Teorii" 26. Poznań 2016, Adam Mickiewicz University Press, pp. 185-194. ISSN 1644-6763. DOI 10.14746/pt.2016.26.12.
\end{abstract}

The last volume of poetry by Stanisław Barańczak, titled Chirurgiczna precyzja (Surgical precision) features the poem Za szkłem (Behind glass). It is an extremely ironic and ambiguous work. The interpretation provided in this paper points to the exceptional importance of this text for Barańczak's poetry as a whole.

Jak na porządnego strukturalistę przystało, Barańczak preferował przejrzyste i precyzyjne konstrukcje. Przystępując więc na przykład do wykładu założeń i powinności tłumacza Szekspira, sformułował „Teorię Trzech Truizmów Translatorskich"1, która szybko stała się kwadratem przekładowych obowiązków. W monografii zaś Białoszewskiego opisał tę twórczość w odniesieniu do trzech rejestrów języka. Po wielokroć posługiwał się ujęciami binarnymi, co znalazło wyraz choćby w częstotliwości pojawiania się spójnika „i” w tytułach książek. Takie strukturalistyczne myślenie organizowało również wiele składników poezji Barańczaka. Rzecz jasna, intencją pisarza i badacza były układy niejednoznaczne, zdynamizowane, o czym przypominam, gdyż w recepcji jego tekstów nie brakowało statycznych schematów. Tymczasem już w pierwszym tomie krytycznoliterackim autor opowiedział się nie tyle za „współistnieniem sprzeczności”, ile za „walką sprzeczności”2.

Podobne napięcie określa całe pisarstwo Barańczaka, tak różnorodne przecież, a zarazem przekonująco spójne. Opozycja ta pojawia się również między okładkami niektórych pojedynczych książek. Przed laty zastanawiał się Tadeusz Nyczek nad gatunkowym rozrzutem jednego ze zbiorów krytycznoliterackich, w którym przecież zamieszczone tam artykuły, eseje, recenzje, polemiki itp. dobrze do siebie pasowały. Niemniej

1 Zob. S. Barańczak, Ocalone w ttumaczeniu. Szkice o warsztacie tłumacza poezji $z$ dodatkiem małej antologii przektadów-problemów, Kraków 2004, s. 194-196.

2 Zob. tenże, Nieufni $i$ zadufani. Romantyzm i klasycyzm $w$ młodej poezji lat sześćdziesiatych, Wrocław 1971, s. 14-15. 
trzeba posiadać wyjątkowo sprecyzowany system wiar i przekonań, by zdecydować się na taki zabieg, który w każdym innym przypadku spowodowałby powstanie li tylko chaotycznego zbioru przypadkowych tekstów, dokumentujących najwyżej rodzaj obecności autora w bieżącym życiu literackim. Etyka $i$ poetyka jest bodaj najśmielszym przypadkiem takiej decyzji powstałym w powojennej praktyce krytycznej, ale też równie rzadko spotkać można po prostu równie precyzyjny system preferencji autorskich ${ }^{3}$.

Owszem, Nyczek nie jest przesadnie powściągliwy w szafowaniu superlatywami, wystarczająco wiele powodów przemawia jednak za takim wyróżnieniem wspomnianego tomu Barańczaka. A przytaczam tę opinię, żeby za jej pomocą wyjaskrawić tezę niniejszego szkicu: otóż z Chirurgiczna precyzją sprawa przedstawia się poniekąd odwrotnie. To niewątpliwie najbardziej zróżnicowana wewnętrznie poetycka książka Barańczaka, co szczególnie dobrze widać w zestawieniu z dwoma (wręcz) absolutnie spójnymi tomikami poprzednimi, Podróża zimowa i Widokówka z tego świata. Wielość gatunków liryki, po które sięgnął Barańczak w ostatnim (jak się okazało) tomie, nie wyczerpuje problemu. Oprócz „zwykłych" wierszy pojawił się tu drukowany wersalikami Tekst do wygrawerowania na nierdzewnej bransoletce, noszonej stale na przegubie na wypadek nagłego zaniku pamięci, utwór wyjątkowo jak na późniejszą twórczość poety bez rymów, niemniej ściśle zrytmizowany. Tuż po słynnym olśniewającym erotyku Płakała $w$ nocy, ale nie jej płacz go zbudzit następuje zestaw Piosenek, nie śpiewanych Żonie (wyłacznie z małodusznego braku wiary we własne możliwości wokalne); jedna z tych piosenek ułożona została z magnetycznych klocków umieszczanych na drzwiach lodówki. Ta różnorodność jawi się jako wręcz manifestacyjna. I nie idzie bynajmniej o to, że Chirurgiczna precyzja okazać by się miała zbiorem cokolwiek przypadkowym. Części składowe tomu podkreślają natomiast właśnie odmienność, dopasowanie niekoniecznie oczywiste, wielokierunkowość. Tak sfunkcjonalizowana konstrukcja znaczy zarówno w obrębie tej książki, jak i w relacji pomiędzy nią a dotychczasową poezją Barańczaka. Nie wykluczam, iż intencją takiego właśnie ułożenia tomu (i o takim tytule!) było zakwestionowanie - a na pewno zapytanie o tę część recepcji, w której poezja przekonanego zwolennika idei nieufności domykała się łatwo i bez zgrzytów. A przecież, jeśli można użyć i takiej pary terminów, cały czas chodzi również o entelechię i entropię. „Nasze podanie pójdzie prawdopodobnie do kosza"4 - autor nie wykluczał tej możliwości, zmierzając do końca tytułowego eseju Tablicy $z$ Macondo. Gatunek

3 T. Nyczek, Powiedz tylko stowo. Szkic o poezji „Pokolenia 68”, Warszawa 1985, s. 210.

${ }_{4}^{4}$ S. Barańczak, Tablica z Macondo. Osiemnaście prób wyttumaczenia, po co i dlaczego się pisze, Londyn 1990, s. 233. 
piśmiennictwa użytkowego jest tutaj autoironiczną alegorią zasadniczego tekstu egzystencjalnego, przygotowanego z poszanowaniem trudnych reguł sztuki pisarskiej. To wszystko zmierza zatem pewnie do nieuniknionej przegranej; czytano zaś Barańczaka w sposób przeważnie budujący.

W Chirurgicznej precyzji znalazł się wiersz Za szkłem, utwór doprawdy szczególny. Przede wszystkim - tak, w przypadku Barańczaka jest to hierarchia uzasadniona - coś dziwnego dzieje się tutaj z rymami. O ile współbrzmienia klauzul są nieraz w jego poezji skomplikowane, lecz zawsze tworzą systematyczny i konsekwentny układ, o tyle w $\mathrm{Za}$ szkłem porządek rymów wskazać raczej trudno. Wers 1 . rymuje się z 10., 11., 14. i 22.; wers 2 . z 5., 26. i 28., ale pojawia się też kilka (osobno) współbrzmiących bliskich par: 30. i 31., 38. i 39., 40. i 41. Są też pary oddalone, np. 3. i 8. lub 37. i 42. Nie da się tu mówić o rymach regularnych.

Zjawisko to okazuje się fonetycznym sygnałem inności całego utworu. Różni się on sporo od pozostałych tekstów z tomu, jak i praktycznie od wszystkich wierszy autora, począwszy od tomu Sztuczne oddychanie. Niektóre partie $Z a$ szkłem warto by intrygująco zestawić z metaforyką i obrazowaniem pierwszych książek Barańczaka, Korekty twarzy i Dziennika porannego. Konstatowanie powrotu do tamtej poetyki czy radykalnego przewartościowania, które proponuje późny Barańczak, byłoby przesadą. Na pewno jednak $Z a$ szktem i cała Chirurgiczna precyzja mają być również inną jakością̧.

W samo południe. Kuchnia. Ogórki swą małosolność znoszą z opartą wprawdzie na solidnej podstawie dna słoja, ale naiwną ufnością w naprawę tej krzywdy, w ogóle w pomyślniejsze, co najmniej średniosolne jutro ${ }^{6}$.

Tekst rozpoczyna się powtórzeniem polskiej wersji tytułu znanego filmu Freda Zinnemanna z Garym Cooperem w roli głównej. Aktor pojawi się raz jeszcze pod koniec utworu, zatem przywołanie tego obrazu nie jest przypadkowe - ale i nie do końca serio. $W$ samo południe należy wprawdzie do klasyki kina, lecz jest to tylko western. Jeśli proponowana w ten sposób hierarchia gatunków gorszyłaby zwolenników aesthetic correctness, spieszę z uzasadnieniem. Otóż na początku lat siedemdziesiątych

${ }^{5}$ Por. ,Za szkłem to piękny, poetycko brawurowy wiersz, jakoś radykalny i [...] maksymalistyczny $\mathrm{w}$ docieraniu do esencji czasu, historii, biografii i języka. Wiersz będący pochwałą idiomu, a na płaszczyźnie indywidualnej poetyki Barańczaka swoiście rewoltujący. To jakby powrót lingwizmu". J. Kandziora, Ocalony w gmachu wiersza. O poezji Stanistawa Barańczaka, Warszawa 2007, s. 276.

${ }^{6}$ S. Barańczak, Za szkłem, [w:] tenże, Wiersze zebrane, Kraków 2014, s. 467. Pozostałe przytoczenia z wiersza za tym samym źródłem, s. 467-468. 
ubiegłego wieku publikował Barańczak na łamach poznańskiego „Nurtu” cykl felietonów Odbiorca ubezwłasnowolniony i w jednym spośród tych tekstów zajął się właśnie westernem, nie omieszkując przywołać przy okazji paragenologicznego określenia: „końska opera”.

\begin{abstract}
Aby możliwa była sytuacja, organizująca fabułę W samo południe, widz musi być pewien, że pozytywny szeryf nie może stchórzyć i uciec z miasta przed bandytami (chwilowe wahania bohatera wcale tu naszej pewności nie osłabiają). Aby możliwe były setki innych, bardziej stereotypowych sytuacji, odbiorca przyjąć musi cały kodeks honorowy świata westernu [...] świat taki w gruncie rzeczy obcy jest wszelkiemu tragizmowi. Tragizm jest bowiem niemożliwy w sytuacji, gdy bohater sprowadzony jest do roli marionetki, na tyle posłusznej konwencjonalnym nakazom zachowań, że jego działanie zawsze da się przewidzieć7.
\end{abstract}

(Ewentualne) pytanie o to, dlaczego western miałby być tragiczny, łatwo uchylić, odwołując się do estetyki Barańczaka, w której kultura masowa istnieje obok wysokiej, obie podlegają przy tym jednorodnej aksjologii (pisał o tym autor przekonująco w Czytelniku ubezwłasnowolnionym). W takim estetyczno-wartościującym systemie kategoria tragizmu pozostaje niezbywalna. Przypomnieć warto przy okazji, iż N.N., bohater Sztucznego oddychania, w jednej z części poematu cierpi z powodu niemożliwości tragedii.

Tak tedy przywołanie na samym początku wiersza westernu ustanawia ironiczną sytuację intertekstualną. Dalej dzieją się równie ciekawe rzeczy. Otóż pewna faza, by tak rzec, kulinarnej chemii, staje się cechą aksjologiczną. Skoro spodziewana średniosolność lepszego jutra (postawa oczywiście również przedstawiona z dystansem) ma być czymś lepszym, to małosolność jawi się jako (przejściowy) etap niedostatku. Koncept Barańczaka wychodzi więc od operacji lingwistycznej.

Antoni Libera tak oto skomentował przepisany powyżej fragment wiersza:

Być może bycie w Czasie to proces dojrzewania - niczym ogórków w słoju? ( $\mathrm{Za}$ szkłem) Dziś jesteśmy jeszcze: „małosolni”, „średniosolni”, „niedo-solni” - i dlatego czekamy, widząc wszystko przez szybę, która zniekształca obraz [niczym zwierciadło u świętego Pawła w I Liście do Koryntian - A.P.]. Ale jutro, gdy dojrzejemy, kto wie, może i pełniej będziemy istnieć? Zapominamy jednak, że czekanie ogórków na ich „pełnosolność” to ich... niedoczekanie. Bo zanim do tego dojdzie, zostaną wcześniej zjedzone ${ }^{8}$.

7 Tenże, Western, czyli tragizm geometryczny, „Nurt” 1973, s. III (okładka).

${ }^{8}$ A. Libera, $O$ „Chirurgicznej precyzji” Stanistawa Barańczaka, „Zeszyty Literackie” 1999, nr 1, s. 158. 
Iwona Misiak dostrzegła zaś w Za szkłem temat gnostycki9. Podobnie Tomas Venclova, który pisał o „dualizmie i związku cierpiącej, zakażonej gniciem materii i ducha, który ją rozświetla" 10 .

Zgoda, można i tak. Czy jednak przywołani interpretatorzy skłonni byliby sądzić, że Barańczak proponuje alegorię poddającą się wcale jednoznacznej - i wyłącznie poważnej - wykładni? Czyżby budował znaczenia wiersza jak, nie przymierzając, oświeceniowi twórcy bajek? Znacznie ciekawszy wydaje się sam pomysł antropomorfizacji ogórków, społecznej zresztą, przeprowadzony pozornie całkiem serio. Przecież jest to koncept tak wyraźnie literacki i metaliteracki (autotematyczny) zarazem, że przede wszystkim - a przynajmniej najpierw - skupia uwagę na sobie; tym bardziej że kontynuacja będzie równie zaskakująca jak domniemana ogórkowa alegoria:

„Czas to najlepszy lekarz”. „Czekaj, to doczekasz”. Przysłowia ogórków mają zawsze w środku tę rezolutną pestkę zaimka „to” i tę prostą godność sumiastych wileńszczyzn i podkarpaci sprzed pierwszej światowej. Ogórek mimo niepiśmienności powinien nazywać się pigoń „pigoń marynowany, sałatka z pigoniów” - za swoją wytrwałość w konserwowaniu ducha języka: „Wolno-ć, ogórku, w swoim słoju", mruknie zawsze poprawnie, [...]

Ogórki, o czym powszechnie wiadomo, nie śpiewają, chociaż - jak okazuje się u Barańczaka - zwykły powtarzać przysłowia. Do Gałczyńskiego sięgam nie bez powodu: w Dlaczego ogórek nie śpiewa antropomorfizacja jest jawnie purnonsensowa, o czym nie zaszkodzi pamiętać w przypadku tłumacza i entuzjasty angielskich oraz amerykańskich purnonsensistów. Nie sposób więc wykluczyć tezy, w myśl której (wszelkie) sensy przypisywane wierszowi są, a z całą pewnością mogą być podminowane absurdem.

W każdym razie - i domysł ten nie jest przesadnie ryzykowny - autor kontynuuje dominantę lingwistyczną. Porzekadła ogórków warte są więc uwagi ze względu na powracający w nich zaimek. Dalej poeta wprowadza ciąg eponimów ze szczególnie intrygującym pigoniem. Co pod pewnymi względami jeszcze ciekawsze, pochwała poprawności wyrażenia „wolno-ć” odnosi się do ortografii, ogórek zaś za każdym razem należycie „mruknie”. Czy można wypowiedzieć łącznik? Pytanie nie od rzeczy w przypad-

${ }_{9}$ Zob. I. Misiak, Stanisława Barańczaka dialog chirurga i demiurga, „Teksty Drugie” 2007, nr 3, s. 87-89.

10 Zob. T. Venclova, $O$ „Chirurgicznej precyzji” Stanistawa Barańczaka, „Zeszyty Literackie" 1999 , nr 1, s. 166. 
ku autora, który wnikliwie zanalizował zapisywanie języka mówionego przez Białoszewskiego. „Wolno-ć, ogórku, w swoim słoju” jest oczywiście parafrazą powiedzenia o proweniencji ludowej, zapisanego przez Fredrę $\mathrm{w}$ tekście literackim ${ }^{11}$. Ortografia $\mathrm{z}$ dywizem jawi się jako synekdocha dawnego, utraconego porządku; świat pigoniów został bowiem w dzisiejszych czasach (użycie wyświechtanego wyrażenia, jak się okaże, jest tu uzasadnione) zanegowany.

\author{
[...] gdy w miastach \\ kran gazety rozwadnia i odwania czosnkowy wigor \\ porzekadła, przejęzyczając „wolno-ć” w bezmyślną „wolność”; \\ w dodatku, jak ołów w wodę, gubią dywiz niechlujni zecerzy - \\ czcionka, rzecz jasna, wstanie z odpowiedniej przegródki w kaszcie, \\ ale w Dzień Sądu; na razie każdy re-make Ostatniej Wieczerzy \\ lub serial „Vade-mecum ${ }^{12}$ giełdowe” telewizyjne programy \\ reklamują, stosując zapis łączny; błagam, nie każcie \\ mi żyć w tej epoce uproszczeń. [...]
}

Przypomina się zaraz „od Uproszczenia umyst zbaw”13 z modlitewnej pieśni Podróży zimowej, niejedyne międzytekstowe nawiązanie autora w obrębie jego własnej twórczości... Opozycja dawnych i nowych czasów zastanawia w tym wierszu ze względu na jej jaskrawość i, wydawać by się mogło, jednoznaczną kontrastową aksjologię. Egzemplifikacja krytyki języka (i) współczesności budzi przecież wątpliwość, skoro łączna pisownia „remake” i „vademecum” pojawia się nie tylko w drukach masowych (jak programy telewizyjne), ale i w naprawdę porządnych słownikach. Ba! nawet sam Pigoń w wydaniu krytycznym Pism wszystkich Fredry publikuje bezłącznikowy zapis: „Wolnoć Tomku, / W swoim domku”14! Również we wcześniejszym Stowniku warszawskim brak dywizu, i przysłowie przedstawia się właśnie tak: „Wolnoć, Tomku, w swoim domku”15. Owszem, postać przemawiająca w wierszu mogłaby konsekwentnie zbyć

11 Zob. H. Markiewicz, A. Romanowski, Skrzydlate stowa, Warszawa 1990, s. 209.

12 Żeby nie skłamać, wyrażenie to zostało wydrukowane z dywizem tylko w osobnym wydaniu tomu Chirurgiczna precyzja, Kraków 1998, s. 53. W obu natomiast edycjach Wierszy zebranych - w wykorzystanej w niniejszym szkicu oraz poprzedniej z roku 2006 - widnieje zapis „Vademecum”, będący wszak przedmiotem namiętnej krytyki wygłaszanej w wierszu.

${ }^{13}$ S. Barańczak, XXIII (Gdy świeci nam neonów blask...), [w:] tenże, Wiersze zebrane, s. 415 .

${ }^{14}$ A. Fredro, Pawet i Gawet..., [w:] tenże, Pisma wszystkie, t. XII: Wiersze. Część druga, Warszawa 1962, s. 64, 65.

15 J. Karłowicz, A. Kryński, W. Niedźwiedzki, Słownik języka polskiego, t. VII, Warszawa 1919, s. 689 . 
te przykłady krytyką postępów czynionych przez językowy uzus i nadal bronić normy, gdy ona nią być przestała.

Jerzy Kandziora w swoim sugestywnym i imponującym odczytaniu wiersza wychodzi od uznania „ogórków małosolnych” za idiom prowadzący do idiolektu mocno nacechowanego sensami egzystencjalnymi.

Wszystko, co poprzednio opowiedziano w wierszu, spotyka się w jego [podmiotu narracji] biografii, której nie da się oddzielić od tamtej prehistorii, która się w niej nawarstwiła, z której się ta biografia wyłoniła do samodzielnego życia, do sprawdzania tego wszystkiego, do buntu, nieufności, wolności ${ }^{16}$.

Owszem, naszkicowana w wierszu przeszłość sprzed pierwszej światówki istnieje $\mathrm{w}$ świadomości przemawiającego $\mathrm{w}$ nim bohatera - chyba jednak nie bardziej, niż w świadomości (statystycznego? modelowego?) uczestnika kultury polskiej. Autobiograficzna postać z wierszy Barańczaka nie jest stamtąd, nie wywodzi się z Kresów. Nie przebijam interpretacji Kandziory zdroworozsądkową kontrą. Chodzi o to, że poznańsko-harwardzki poeta nie potrzebował podbudowywać swoich tekstów tożsamością kresową - ani żadną inną dookreśloną geograficznie. Zgoda, nietrudno wskazać w jego poezji liczne właśnie geograficzne konkrety, poznańskie czy nowoangielskie, nie jest on przecież pisarzem nostalgicznym, małoojczyźnianym. Nazwa ulicy lub miejscowości funkcjonuje u Barańczaka na prawach realistycznego i egzystencjalnego detalu, nie stanowi natomiast pars pro toto regionalnej tożsamości. Owszem, wyjątkowo wykorzystuje on leksykę gwarową, niemniej są to przedsięwzięcia lingwistyczne, nie zaś kryptokomunikaty wskazujące na (waloryzowaną dodatnio) przynależność bohatera do lokalnej wspólnoty. Ciekawe zresztą, że wiersz tak mocno afirmujący społeczność, w której znalazł się bohater, jest właściwie utopijną wizją wspólnoty (Po przejściu huraganu „Gloria”).

No i czy „ogórki małosolne” naprawdę są idiomatyczne? W słowniku polsko-angielskim są odpowiedniki przymiotnika „małosolny”, co świadczyłoby na rzecz jego ponadlokalnego obiegu. Nie wykluczam zresztą, że obraz słoja z małosolnymi ogórkami nie musi wcale być poznańską (czy szerzej: wielkopolską) reminiscencją. Gdyby nie zapisana kiedyś przez Barańczaka uwaga o podręcznym środku interpretacji, jakim jest telefon, zapytałbym panią Annę, czy takie słoje z kiszącymi się ogórkami były ustawiane również w kuchni w Newtonville. Całkiem serio zaś: nigdzie $\mathrm{w}$ wierszu nie ma podanego czasu ani miejsca, w których bohater widział/widzi wypełnione wiadomymi warzywami szkło, początek (to znaczy

16 J. Kandziora, Ocalony w gmachu wiersza..., s. 276. 
sam słój) nie musi zatem oznaczać ani przeszłości, ani polskich realiów. Iwona Misiak zestawia $Z a$ szkłem z przetłumaczonym przez Barańczaka wierszem Wallace'a Stevensa Anegdota o stoju17, co przesuwa akcent z domniemanej lokalności na intertekstualną złożoność.

Wracam do kontrastu między niegdyś a dziś. Zgoda, krytykę uproszczeń współczesnych bohater wiersza podzielał niewątpliwie z autorem. Czy jednak pigoniowe wileńszczyzny i podkarpacia byłyby utraconym złotym wiekiem? Niekoniecznie. Ortografię miały wprawdzie bardziej złożoną, nie bez powodu przecież tamta kultura przedstawiona została $\mathrm{w}$ wierszu w sposób wyzywająco stereotypowy ${ }^{18}$.

Czas tamtej kultury zbiega się zresztą z (rozumianym szerzej) przełomem modernistycznym w kulturze polskiej, co łączy się przecież z metaforą „kran gazety”, która jest podjęciem modelu Peiperowskiego (a więc też sygnałem wskazującym na wczesną poezję Barańczaka).

\section{[...] Świadomość, że z nią [epoką uproszczeń] nie wygramy, ogórki przyjmują w sposób, w jaki wartownik u bramy znosi szturchanie lizakiem przez małą dziewczynkę: stojąc na baczność, wciąż z godnością, niemą jak ryba w tej wodzie z koprem, mętnej i wspólnej: [...]}

Postać małej dziewczynki kilkakrotnie w pisarstwie Barańczaka powracała (wiersze Co jest grane i Nazajutrz, felieton Dziewczynki wręczajace kwiaty, od którego zaczął się cykl Odbiorcy ubezwłasnowolnionego), służąc autorowi do odsłaniania semantycznych manipulacji. Jest to więc postać, by tak rzec, szczególnie dotkliwa: wartownik wprawdzie nie zostaje przez nią pokonany, lecz jest - trochę na modłę Gombrowicza dutknięty. Lepkość takiego śladu (a wśród przełożonych przez Barańczaka wierszy Ogdena Nasha jest również ten o stanie klawiszy fortepianu dotykanych dziecięcymi palcami, mocno naznaczonymi przez słodycze) staje się również czymś w rodzaju nieusuwalnego ośmieszenia. Uproszczenie jako składnik? efekt? przyczyna? kultury infantylizującej to niezły trop. Nie proponuję tu alegorezy, zawsze (powtórzę) w tym wierszu ryzykownej. Do wartownika niepokojonego przez dziewczynkę z lizakiem porównane są wszak ogórki... To przecież trzeba powiedzieć: przeciwko uproszczeniu proponuje Barańczak poetycką komplikację wysokiego stopnia, którą tworzy również porównanie skórki ogórków do twarzy Gary'ego Coopera. W filmie Zinnemanna postać kreowana przez tego aktora roz-

17 Zob. I. Misiak, Stanistawa Barańczaka dialog..., s. 89.

18 Kandziora pisze o „«epoce uproszczeń» - kiedyś? teraz?”. Zob. J. Kandziora, Ocalony $w$ gmachu wiersza..., s. 275 [wyr. A.P.]. 
wiązała problem, w zakończeniu wiersza pojawia się natomiast jako jeszcze jeden składnik sensotwórczej nierozstrzygalności.

[...] Twarz z brodawkami i wszystkim, strużką potu, fałdami skóry; ale tak jasno wtedy, ze trzydzieści lat temu, w salce kina „Muza”, na ścianach, na ich tynku i boazerii jej ekranowy odblask wypisywał: wolno-ć, niewierny Tomku, w samo południe, czyli w każdej chwili, wolno ci sprawdzić tę mgiełkę na szkle słoja, krwotok tej szyby, puls gwiazdy, sprawdzać życie, własne, na przegubach świata kładąc półślepe palce.

W samo południe jest filmem czarno-białym, i ponieważ sporo ujęć kręconych było w dziennych plenerach, sala kinowa często bywa oświetlana - tyle że są to mignięcia, nie zaś źródło światła o stałym natężeniu. Zastanawiam się nad tym, gdyż odbicia ekranowego blasku stają się figurą chrystologiczną, skoro adresatem wypowiedzi jest niewierny Tomek, oczywista aluzja do sceptycznego apostoła. W perykopie z Ewangelii Janowej Tomasz otrzymuje możliwość dotykowego sprawdzenia zmartwychwstania, ale z niej rezygnuje. Propozycja Jezusa, ta o palcu i ręce, jest poniekąd wypowiedzią ironiczną: jej celem nie jest umożliwienie Tomaszowi doświadczenia, lecz krytyczne przypomnienie jego empirycznej deklaracji. Inna rzecz, że widzący Jezusa uczeń nie musiał już badać jego ran.

gdy przez każdy moment i miejsce przewlekała się nitka sensu, którego nie chcieliśmy dociec, a na naszych przegubach ucięty palec Thomasa Randolpha wystukiwał bezgłośne akcenty ${ }^{19}$.

To inny przegubowy motyw, jeszcze z Widokówki z tego świata. Oksymorony tworzą tu jeszcze paradoks czy już raczej negację? Joanna Dembińska-Pawelec opatruje finał $Z a$ szkłem takim komentarzem:

[...] miarowy rytm życia, przejawiający się w przestrzeni makrokosmosu planet oraz mikrokosmosu ludzkiego ciała, doświadczany przez puls krwi, obecny jest w wierszu $Z a$ szkłem [tu przytoczenie końcówki tekstu]. Zestawione w synekdochicznym obrazie „puls gwiazdy” i puls krwi wyczuwalny „na przegubach świata” akcentują wzajemną przynależność i wspólnotę człowieka oraz świata ${ }^{20}$.

Obawiam się przecież, że wraz z niewiernym Tomkiem jesteśmy ofiarami ironii, tej poetyckiej i tej absurdalnej, wynikającej z pozostawania

${ }^{19}$ S. Barańczak, Sierpień 1988, [w:] tenże, Wiersze zebrane, s. 370.

20 J. Dembińska-Pawelec, „Poezja jest sztuka rytmu”. O świadomości rytmu w poezji polskiej dwudziestego wieku (Miłosz - Rymkiewicz - Barańczak), Katowice 2010, s. 404. Zob. też s. 412, gdzie autorka komentuje zakończenie Sierpnia 1988 z palcem Thomasa Randolpha. 
w sytuacji raczej neantyzującej. Nie brak bowiem w potencjalnie weryfikującym wyliczeniu Barańczaka sygnałów negatywnych: krwotok szyby, półślepe palce. Niejasny epitet określający palce - dlaczego półślepe? bo sprawdzające $\mathrm{w}$ ciemności? - oraz enumeracyjny rytm każą przywołać jeszcze jeden (i ostatni już w tym szkicu) wiersz poety, mianowicie $\mathrm{Na}$ pustym parkingu za miastem, zaciagając ręczny hamulec:

[...] Gdzieś będzie: nie z własnej woli wybrana sekunda ocknięcia się w ruchu, pośrodku zdyszanego wyznania przecinek stawiany na oślep, na opak, na zawsze ${ }^{21}$.

Sekundę z Pustego parkingu i każdą chwilę z Za szkłem można uznać za wcale podobne miary czasu: wyjątkowe, powtarzalne i niknące na zawsze (stąd dwuznaczność tego określenia). Sprawdzanie świata sprowadza się zaś do niepewnego sprawdzania siebie. Samozwrotność ja? Poniekąd tak, skoro ja nicestwieje wraz ze światem.

Żeby jednak zakończenie nie zabrzmiało zbyt pointująco, nie zaszkodzi jeszcze kilka zdań autokomentarza interpretatora. Otóż wiersze Barańczaka niejednokrotnie wymykały się definitywnym ujęciom, niektóre z rozwiązań zastosowanych przez poetę pozwalały nawet na przywołanie poststrukturalistycznej przecież kategorii nierozstrzygalności. W Kontrapunkcie świadomie użyty niewykonalny rym uniemożliwiał domniemane rozstrzygnięcie. W Obserwatorach ptaków zaś deklaratywny finał podany został w cudzysłowie, co oznaczało również niewiadome autorstwo ${ }^{22}$. W utworze $Z a$ szkłem, przypomnę, rzecz komplikuje się jeszcze bardziej, dlatego też wybrałem nieco inny sposób opisu. Starałem się raczej przybliżać do punktów zawęźleń stylistycznych, znaczeniowych, niż ryzykować (zbyt) uspójniającą wykładnię całości wiersza. Nie wykluczam zresztą, że stychiczna konstrukcja komentowanego utworu jawi się właśnie jako ironiczne zakwestionowanie całości. Zaskakująca antropomorfizacja ogórków małosolnych, do tego konstrukcje metaforyczne wystarczająco różne od tych spotykanych w większości tomów Barańczaka - takie środki stylistyczne powstrzymują interpretatora od przesadnie pewnych swego orzeczeń. I nie proponuję tu (taniej) retoryki, w myśl której analiza jest czymś podrzędnym wobec jej przedmiotu. Nie. Szukałem natomiast $\mathrm{w}$ miarę możności adekwatnego języka opisu, pozostającego (również możliwie) jak najbliżej wiersza, acz na zewnątrz.

${ }^{21} \mathrm{~S}$. Barańczak, Na pustym parkingu za miastem, zaciagajac ręczny hamulec, [w:] tenże, Wiersze zebrane, s. 322 [wyr. A.P.].

22 Kwestie te opisuję dokładniej w osobnych interpretacjach tych wierszy. Zob. A. Poprawa, Bach w samochodzie albo próba kontrapunktu; Migotliwość wartości, [w:] tenże, Formy i afirmacje, Kraków 2003. 